\title{
DETERMINATION OF TRICHOPHYTOCIDAL EFFICIENCY OF SOME DISINFECTION SOLUTIONS USING A SIMPLE ORIENTATION METHOD
}

\author{
M. ŠISÁK, A. RYBNIKÁŘ
}

Bioveta, 68323 Ivanovice na Hané

Received September 10, 1979

\begin{abstract}
Šišák M., A. Rybnikář: Determination of Trichophytocidal Efficiency of Sorne Disinfection Solutions Using a Simple Orientation Method. Acta vet. Brno, 49, 1980: 245-250.

The antitrichophytocidal efficiency was tested of some generally used disinfection preparations and of Mykolastanox F - a preparation used for local therapy of cattle trichophytosis. Tests were performed on 14 and 22-day-old sporulating cultures of Trichophyton verrucosum Bodin 1902. Of all the disinfection preparations the best results were reached with Persteril. It was also found that formaldehyde at a concentration of $4 \%$ had a strong fungicidal effect. The effect of the other disinfection preparations tested in the concentrations used was only fungistatic, or that they virtually did not affect the vitality of the $T$. verrucosum culture.

As far as the effect of Mykolastanox F is concerned it was found that older cultures of T. verrucosum were more resistant. A trichophytocidal effect was reached after a 5-minute application of the preparation in a $0.3 \%$ concentration, or after one minute using the preparation in a $0.5 \%$ concentration.
\end{abstract}

Trichophyton verrucosum, disinfection, Mykolastanox $F$.

Cattle trichophytosis is a dangerous disease contagious to man; its originator is the Trichophyton verrucosum fungus. The germ is very resistant to unfavourable conditions and can survive for a long time in pathological material outside the host organism (Ladzianská and Halaša 1975). A number of preparations was proposed for therapy and disinfection the majority of which was insufficiently effective and considerably expensive. Humpolíčková et al. (1978) performed laboratory estimations of the efficiency of veterinary antimycotics and disinfestants. In the preparations only the fungistatic activity was determined whereas the fungicidal effectiveness was not estimated. Our experiments were based on studies of the authors mentioned above. However, tests of the effectiveness of disinfection preparations used commonly for disinfection in microbiological laboratories and of the Mykolastanox $F$ preparation were performed using the immersing method, thus determining the fungistatic and fungicidal effect.

\section{Materials and Methods}

The antitrichophytocidal activity was determined in the following freshly prepared aqueous: solutions: Orthosan BF-12 $(2 \%, 5 \%$ and $10 \%$ concentrations), Ajatin $(2 \%, 5 \%$ and $10 \%)$, Jodonal $\mathrm{B}(5 \%, 10 \%$ and $20 \%)$, formaldehyde $(1 \%, 2 \%$ and $4 \%)$, soda lye $(1 \%, 5 \%$ and $10 \%)$. and Persteril $(1 \%, 2 \%$ and $4 \%)$. Segments of 14-day-old and 22-day-old Trichophyton verrucosum cultures were dipped into these solutions for one and five minutes (segment diameter was $5 \mathrm{~mm}$ ). The culture of $T$. verrucosum was obtained through propagation on sweet wort agar at a temperature of $28^{\circ} \mathrm{C}$. At a given age the culture represented a group of hyphae with abundant microonidia and sporadically occurring macronidia and chlamydospores. 
After being exposed to the disinfection solutions the segments were rinsed several times in distilled water and transferred onto Petri dishes with Sabouraud agar. In the control experiment the segments were dipped into and rinsed with water in regular time intervals. Incubation was done in darkness at a temperature of $28^{\circ} \mathrm{C}$.

In the second experiment tested were aqueous solutions of Mykolastanox $\mathrm{F}$ (in concentrations of $0.05 \%, 0.1 \%, 0.2 \%, 0.3 \%, 0.4 \%$ and $0.5 \%$ ) again using segments of 14-day and 22 -day-old cultures of $T$. verrucosum. The process was the same as in the preceding experiment, only the periods of exposure were different, i.e. one minute, 5 minutes, 10 minutes, 30 minutes and one hour.

Growth changes were assessed in both experiments in the course of 21 days of incubation macroscopically according to the rate of growth of the culture of $T$. verrucosum in the experimental variant as compared with the control experiment.

Table 1

Effect of some disinfection solutions on the vitality of a 14-day-old culture of Trichophyton verrucosum

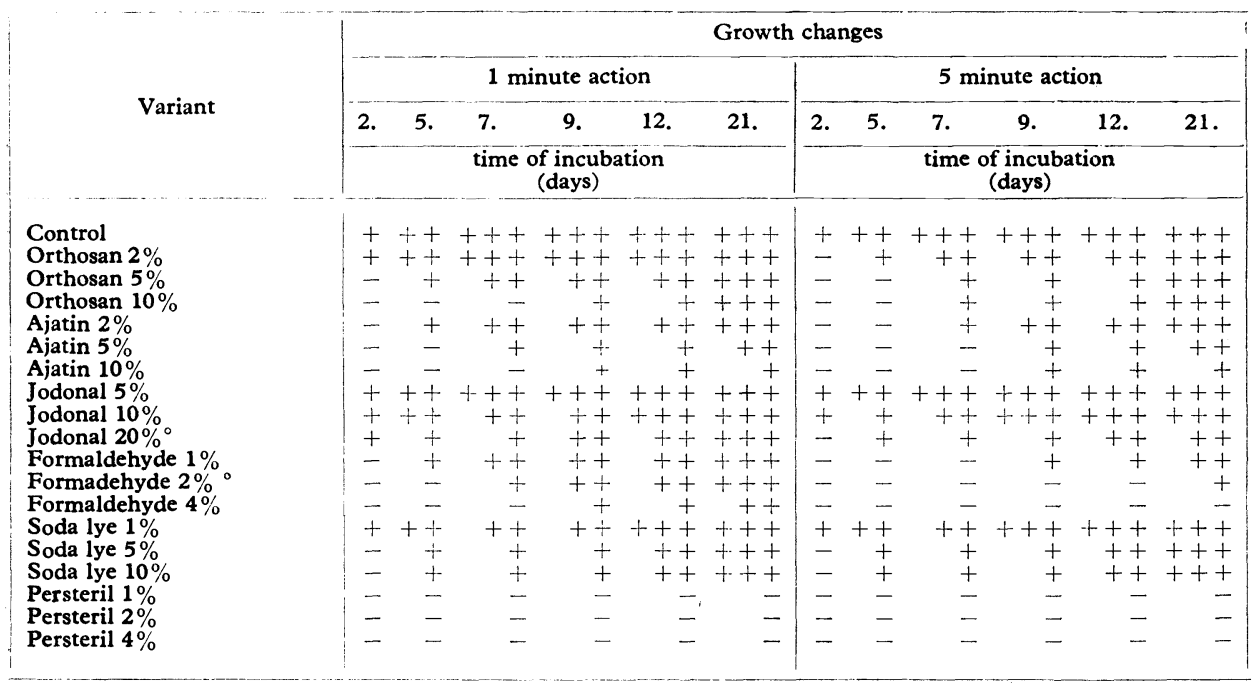

- culture does not grow (macroscopically)

+ weak growth

++ moderate growth

+++ strong growth

\section{Results}

The results of antitrichophytocidal efficiency of disinfection means are given in Tabs. 1 and 2. It was evident that the most effective of all the preparations tested was Persteril. After a five-minute application of this preparation all the concentrations showed a fungicidal effect. Even a $45 \%$ concentration of formaldehyde had a fungicidal effect after a five-minute exposure. The effect of the other preparations tested was only fungistatic; the growth of the culture segments in the variants Jodonal $5 \%$ and $10 \%$, Orthosan $2 \%$, and soda lye $1 \%$ was approximately the same as in the control. When comparing the resistance of cultures of various age no considerable differences were found.

Tests of the Mykolastanox F solutions showed that older cultures (22 days) of $T$. verrucosum were more resistant. At a concentration of $0.5 \%$ this substance had a trichophytocidal effect as soon as after one minute. When the concentration was reduced to $0.3 \%$ and $0.2 \%$ a fungicidal effect occurred within 5 minutes 

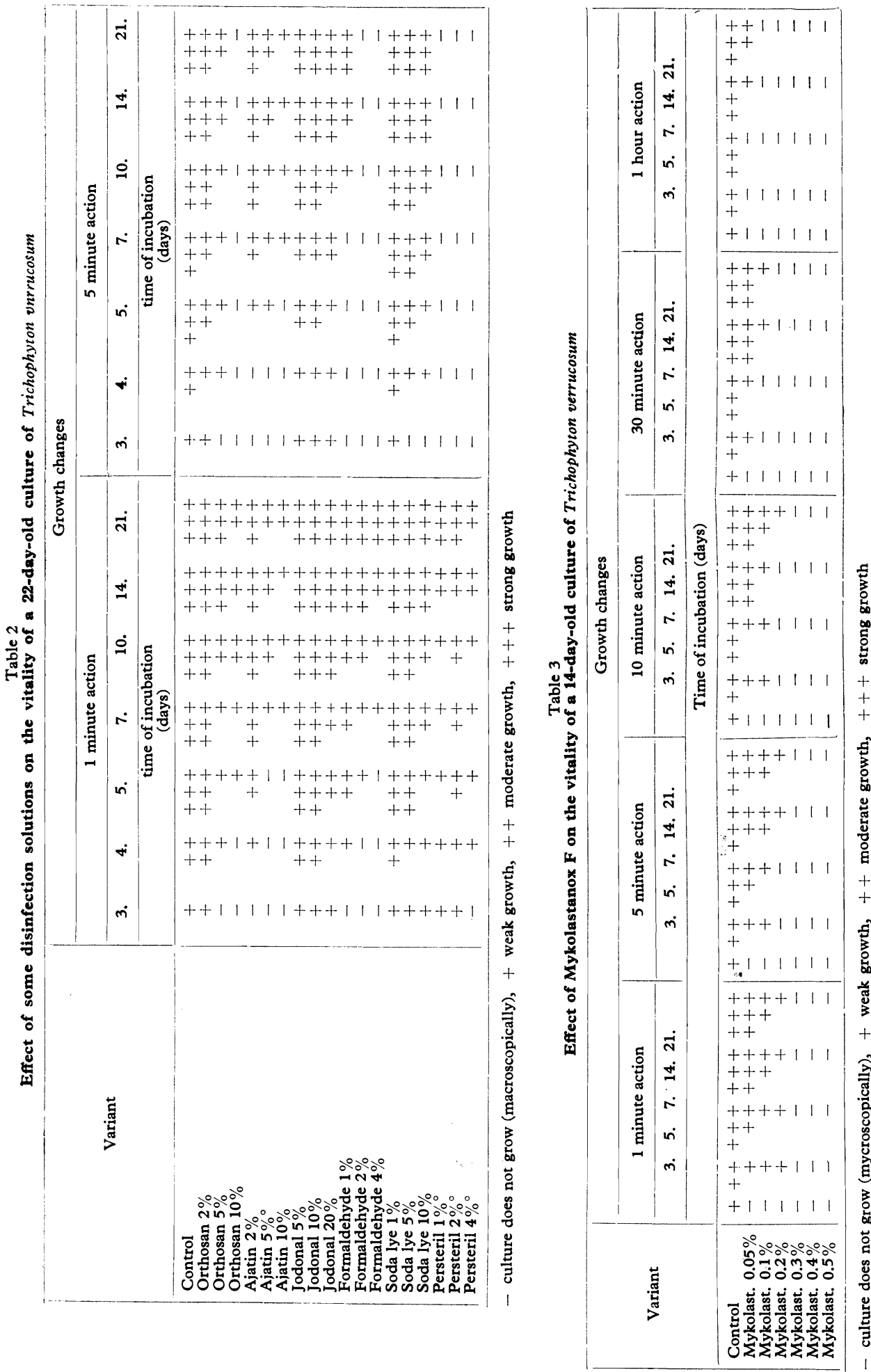
Table 4

Effect of Mykolastanox $\mathbf{F}$ on the vitality of a 22-day-old culture of Trichophyton verrucosum

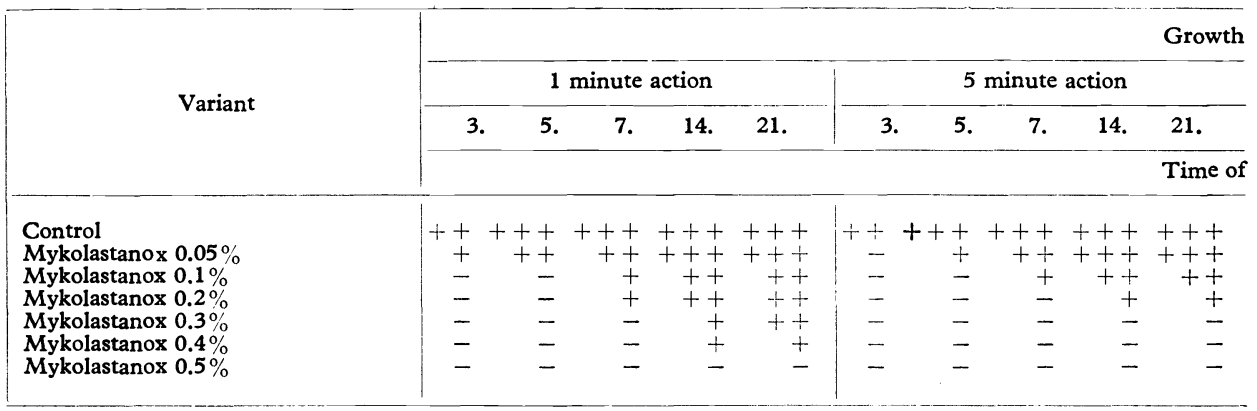

- culture does not grow (macroscopically)

+ weak growth

++ moderate growth

+++ strong growth

and one hour, respectively. The effect of Mykolastanox $\mathrm{F}$ in concentrations of $0.1 \%$ and $0.05 \%$ was only fungistatic, there was no fungicidal effect even after one hour, as can be seen in Tabs. 3 and 4 .

\section{Discussion}

Tkácik (1969) studied the effect of disinfection solutions on the Trichophyton verrucosum fungus in vitro. He reached the best results when using formalin and peroacetic acid. A $1 \%$ concentration of formalin was effective for the fungus from the pathological material after a five-minute exposure. In the authors' experiments, using a cultural fungus form, a $1 \%$ concentration of formalin caused only growth inhibition, whereas, macroscopically, growth was observed after 9 days of incubation. However, it is necessary to note that the authors studied the growth changes only up to 7 days. The same results were obtained when testing peroacetic acid; however, on the contrary, in the variants with soda lye in a concentration of $10 \%$ no fungicidal effects were observed in the authors' experiments as compared with those of Tkáčik.

As far as Persteril is concerned, very good results were obtained also in practice. Krupička and Švec (1965) recommended a once-over local treatment of the affected cattle with peroacetic acid in concentrations from $1 \%$ to $4 \%$. A $1 \%$ concentration of this substance was suitable for the disinfection of barns and equipment. Similar good results were obtained by the German authors Arcularius et al. (1976) who used peroacetic acid against cattle trichophytosis in the form of sprays. For therapeutic and prophylactic effects the most suitable was a $2 \%$ concentration of this substance. The disadvantage of Persteril is its strong corrosive effect and its irritating effect on the eyes of animals and the eyes and hands of operators.

The results obtained with Mykolastanox F proved that its trichophytocidal properties were good. During the tests it was found than in $0.3 \%$ and $0.5 \%$ concentrations its effect was strongly fungicidal even when exposed for a very short time. 


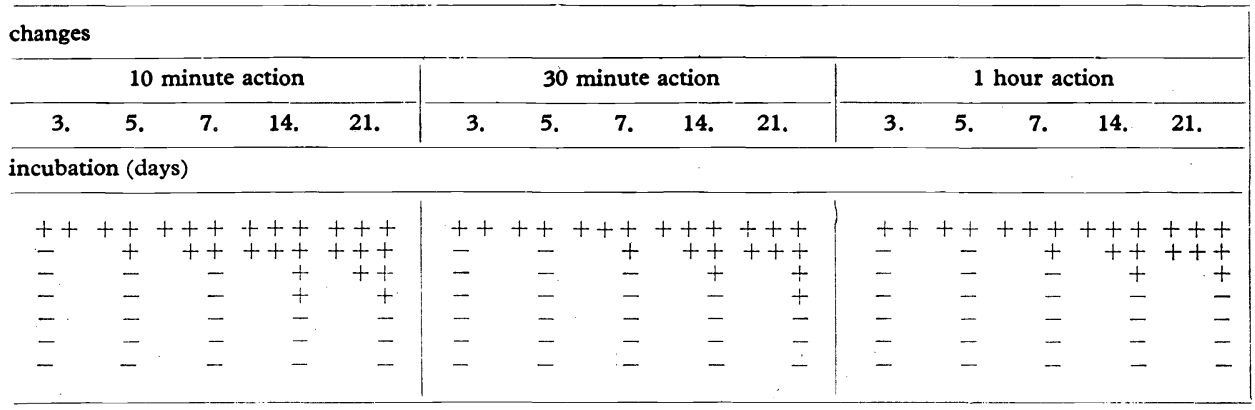

The results of field estimations of the efficiency of Mykolastanox $F$ were very good. With once-over applications of this substance Kováč et al. (1974) managed to cure cattle affected with trichophytosis in $90 \%$, with further treatment they reached $100 \%$. For prophylactic treatment the authors recommend the whole body of the animal to be sprayed with a $0.25 \%$ solution of Mykolastanox F. Šišák et al. (1977) treated animals with Mykolastanox F at a $0.1 \%$ concentration applied in the form of a spray and with Mykolastanox F at a $0.5 \%$ concentration applied on one third of the animal's body. Application of this substance at a $0.5 \%$ concentration gave very good results, however, the application of $0.1 \%$ Mykolastanox $\mathrm{F}$ was not effective enough. These results are in accordance with the results of the present study with tests of Mykolastanox $\mathrm{F}$ in vitro.

The disinfections preparations Orthosan, Jodonal, and Ajatin, commonly used for disinfection in microbiology, proved to be insufficiently effective in the concentrations investigated. That is why the authors do not recommend them for disinfection against Trichophyton verrucosum germs.

\section{Zjištování trichofytocidní účinnosti některých dezinfekčních roztoků jednoduchou orientační metodou}

Byla testována protitrichofytická účinnost některých běžně používaných dezinfekčních prostředků a Mykolastanoxu $\mathrm{F}$ - přípravku určeného $\mathrm{k}$ lokální terapii trichofytózy skotu. Ověrování bylo provedeno na 14denní a 22denní sporulující kultuře Trichophyton, verrucosum Bodin 1902. Z dezinfekčních prostředků bylo dosaženo nejlepších výsledků s Persterilem. Silný fungicidní vliv byl zjištěn také $\mathrm{u}$ formaldehydu $\mathrm{v}$ koncentraci $4 \%$. Ostatní zkoumané dezinfekční prostředky působily $\mathrm{v}$ použitých koncentracích pouze fungistaticky, nebo vitalitu kultury T. verrucosum prakticky neovlivnily.

Pokud jde o působení Mykolastanoxu $F$, byla zjištěna větší odolnost $k$ jeho vlivu u starší kultury $T$. verrucosum. Trichofy tocidního účinku zde bylo dosaženo po 5 minutovém působení prípravku v koncentraci $0,3 \%$ nebo po 1 minutě působení př́pravku v koncentraci $0,5 \%$. 


\section{Выявление трихофитоцидной активности некоторых дезинфицирующих растворов простым ориентировочным методом}

Проверялась антитрихофитическая активность некоторых широко применяемых дезинфицирующих растворов и Миколастанокса $\Phi$ - препарата, предназначенного для местной терапии трихофитоза крупного рогатого скота. Проверка проводилась на спорулирующей культуре Trichophyton verrucosum Bodin 1902 с продолжительностью существования лве недели - 22 дня. Самых лучших результатов из числа дезинфицирующих растворов было достигнуто с Перстерилом. Интенсивное фунгицидное влияние было также выявлено в случае формальдегида в концентрации 4 \%. Остальные дезинфицирующие средства в примененных концентрациях оказывали лишь фунгистатическое воздействие или на жизненность культуры T. verrucosum не оказали фактического влияния.

Что касается воздействия Миколастанокса $\Phi$, то была установлена более высокая устойчивость к его влиянию в случае T. verrucosum старшего возраста. Тихофитоцидной активности здесь было достигнуто после пятиминутного воздействия препарата в концентрации 0,3 \% или после воздействия препарата в концентрации $0,5 \%$ в течение 1 минуты.

\section{References}

ARCULARIUS, K. - LINK, R. - SCHÄFER, R.: Ergebnisse der Behandlung der Trichophytie mit Peressigsãure. Mh. Vet. -Med., 31, 1976: 886-890.

HUMPOLICKOVÁ, V. - OTČENÁSEK, M. - STROS, K.: Orientačni laboratorní hodnocení antimycetární účinnosti veterinárních antimykotik a dezinficiencií. Veterinářství, 28, 1978: $419-420$.

KOVÁC, L. - SAFÁK, J. - DOFEK, R.: Možnosti komplexního tlumení trichofycií u skotu. Veterinářství, 24, 1974: 153.

KRUPICKA, V. - SVEC, J.: Naše zkušenosti s použitím kyseliny peroctové $\mathrm{v}$ ohnisku trichofycie. Veterinářství, 15, 1965 : 456-458.

LADZIANSKÁ, K. - HALAS̉A, M.: Preživanie pôvcdcu trichofytiázy hovädzieho dobytka Trichophyton verrucosum Bodin, 1902, za niektorých podmienok mimo hostitelský organizmus. Veter. čas., 17, 1975: 15-19.

ŠIŚÁK, M. - STROSSA, J. - ŠIŠ́́KOVÁ, E. - JAROŠ, J.: Použití medicinálního lizu $S$ obsahem síry a zinku při léčbě trichofytózy telat. Veterinářství, 27, 1977: 277-278.

TKÁČIK, Š.: Ứinok niektorých dezinfekčných prostriedkov na hubu Trichophyton verrucosum in vitro. Folia vet., 13, 1969: 41-49. 